\title{
CRUCIAL FACTORS FOR IMPROVING THE ISO 14001 ENVIRONMENTAL MANAGEMENT SYSTEM
}

\author{
Joanna EJDYS ${ }^{1}$, Alina MATUSZAK-FLEJSZMAN ${ }^{2}$, \\ Michał SZYMANSKI ${ }^{3}$, Leonas USTINOVICHIUS ${ }^{4}$, \\ Galina SHEVCHENKO ${ }^{5}$, Agata LULEWICZ-SAS ${ }^{6}$ \\ 1,6 Bialystok University of Technology, Tarasiuka 2, 16-001 Kleosin, Poland \\ ${ }^{2}$ Poznan University of Economics, Niepodleglosci 10, 61-875 Poznan, Poland \\ ${ }^{3}$ Technical University of Gdansk, ul. Narutowicza 11/12, 80-952 Gdansk, Poland \\ ${ }^{4,5}$ Vilnius Gediminas Technical University, Sauletekio al. 11, LT-10223 Vilnius, Lithuania \\ E-mails: ${ }^{1}$ j.ejdys@pb.edu.pl (correspondingauthor); ${ }^{2}$ alina.matuszak@poznan.pl; \\ ${ }^{3}$ msz@zie.pg.gda.pl; ${ }^{4}$ leonas.ustinovicius@vgtu.lt,l.ustinowicz@pb.edu.pl; \\ 5galina.sevcenko@vgtu.lt; 6a.lulewicz@pb.edu.pl
}

Received 03 December 2014; accepted 22 June 2015

\begin{abstract}
The practice of using environmental management systems (EMS) ISO 14001 at the organisational level indicates that the efficacy of such solutions depends on many factors, both endogenous and exogenous in nature. This article aims to identify the factors that determine the opportunities for the improvement of EMS in organisations, the analysis of the relationship between the factors and the classification of the factors due to their role in the system improvement. The structural analysis was used to classify and identify the key factors and then to categorize these factors into five groups. Finally, the role of these key factors in improving environmental management systems was examined. Based on the findings, guidelines can be offered to both scholars and practitioners regarding the factors crucial for the improvement of the EMS. Aiming to add value to the existing literature, the structural analysis was adapted to classification and identification of the key factors. From the point of view of practitioners, it seems to be very profitable to concentrate on the crucial factors during the process of EMS improvement.
\end{abstract}

Keywords: ISO 14001, continual, improvement, structural analysis, crucial factors, environmental management systems.

JEL Classification: L15, C61.

\section{Introduction}

The ISO14001 environmental management system is premised on the concept of continual improvement, propounded by W. E. Deming (1986). According to the ISO 14001 standard, an EMS is "the part of the overall management system that includes organisational structure, planning activities, responsibilities, practices, procedures, processes and resources for developing, implementing, achieving, reviewing, and maintaining the environmental policy" (ISO 14001 Final Draft 2015). 
The system is intended to function by providing a company with a source of benefits that are subject to quantification and assessment. In practice, however, continuous improvement is one of the most difficult aspects of the system to prove during certification or conformity audits. Also, while management systems yield easily identifiable benefits, they can also serve as a source of various problems. Another shortcoming of the ISO14001 standard is that it lacks an operational definition of what constitutes continuous improvement and how it can be assessed (Brouwer, (Kris) van Koppen 2008).

Improvement of a management system is a domain that is devoted to the development of an organisation. Improvements to operations in an organisation can vary from slight changes, introduced in a continuous manner, to continuous improvement measures (Peiro-Signes et al. 2013; Medineckiene et al. 2010; Radziszewska-Zielina 2011; Tamošaitienè et al. 2013). Regardless of the type of the improvement process, it should be carried out in accordance with the stipulations of the Deming cycle: Plan-Do-CheckAct (PDCA).

Based on the standard requirements of PN-EN ISO 9004, the continuous improvement process should be a part of the organisational culture, mainly through: allowing the staff of the organisation to participate in improvement actions by authorising them to take part; providing essential resources; setting up a recognition and reward system in the improvement process; and continuous efficiency as well as effectiveness improvement of the improvement process itself (ISO 9004: 2009).

Improvement as a process should not be limited to action-reaction situations but rather ought to be regarded as a process that has a long-range perspective, foresees changes and keeps the organisation up to date with the most recent trends. From the outset, improvement processes of normalised management systems should emphasise the fact that normalised management systems are the next phase in achieving perfection (Granly, Welo 2014; Rybka et al. 2013; Junnila, Ristimäki 2012; Tambovceva, Geipele 2011).

Taking into account the fact that improvement is a continuous process, it is crucial to identify the factors that play a significant role in the improvement process of the environmental management system ISO 14001 (Stevens et al. 2012; Hwang, Leong 2013).

This article aims to identify the factors that determine the opportunities for improvement of environmental management systems in organisations, the analysis of the relationship between the factors and the classification of the factors due to their role in the system improvement.

The remainder of this paper is arranged as follows: the first part of the article presents the results of a literature review (Zhang et al. 2014; Kobylińska 2014; Masternak-Janus 2013; Lulewicz 2013), whose primary objective was to identify the factors determining the processes of improvement of environmental management systems. As a result of the literature review, 15 factors most frequently cited in scientific research were identified. These factors, in the further part of the article, provided the authors with the basis for their classification made using the applied structural analysis. To this end, the second part of the article includes a detailed characterisation of the structural analysis, along with the indication of the current applications. The last part of the article presents the 
results of own research and a discussion of the results obtained in the context of previous studies on the determinants of the improvement of environmental management systems. Finally, fifteen factors were categorized according to their role and weight in the improvement process of the environmental management system.

\section{Literature review}

Continuous improvement is a vital attribute of an effective environmental management system. The ISO 14031, which is a member of the ISO 14001 family, provides guidance on the use of environmental performance evaluation to organisations, regardless of their type, size, location and complexity. The ISO 14031 standard elaborates on how environmental performance is measured and offers a description of environmental performance (Brouwer, (Kris) van Koppen 2008). It is possible for the environmental management system to achieve continuous improvement by carrying out environmental objectives as well as by general improvement of environmental management or any of its elements. The ISO 14001 standard advises an organisation to continuously evaluate the outcome of its environmental activity in order to identify areas for improvement (ISO 14001: 2015; ISO 14004: 2004; Heras-Saizarbitoria, Boiral 2013). The analysis of the continuous improvement process can be carried out from two perspectives (Fig. 1).

To date, environmental management systems have been the subject of a great deal of scholarly inquiry. In particular, researchers have focused their analyses on the impact ISO 14001 has on environmental outcomes-performances (Testa et al. 2014; Zivkovic et al. 2013; Zobel 2013; Comogli, Serena 2012; Boiral, Henri 2012; Franchetti 2011; Gomez, Rodriguez 2011) and the identification of internal and external factors that impact upon the process of continuous improvement in companies (Brouwer 2004; Ratcliffe 2000; Ejdys, Matuszak-Flejszman 2010; Neugebauer 2012; Kim et al. 2013). Several studies mention variables that moderate the relationship between an independent variable (ISO 14001 implementation) and a dependent variable (environmental or business performance) (De Jong et al. 2014; Berliner, Prakash 2013; De Vries et al. 2012).

The authors of this article focused in particular on the determinants of the improvement processes.

Identification of determinants that are crucial in the improvement processes is an important element of the improvement process itself. Newman and Breeden (1992) contend that one of the most crucial factors in the maintenance and improvement of the environmental management system is the ability of the top management to envision environmental activities and at the same time provide the essential resources to achieve them. Moreover, Newman and Breeden argue that it is essential to include environmen-

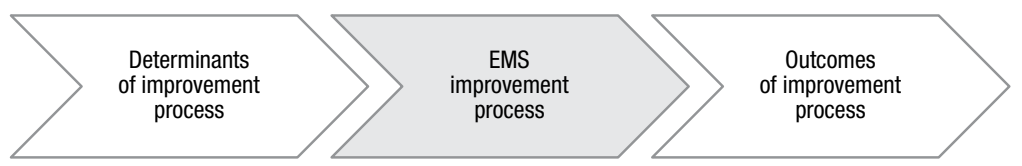

Fig. 1. Different approach to the analysis of the improvement process 
tal actions in all processes carried out in a given organisation, as well as to delineate staff responsibilities, and to carry out environmental actions resulting from the environmental management programme. Motivation has also been identified as a critical factor: staff members should be rewarded for taking an active part in achieving previously set goals and undertaking environmental actions resulting from the system's approach to environmental management (De Oliveira Baumbach et al. 2013; Srdić, Šelih 2011; Ciegis et al. 2008).

Conclusions derived from a review of the existing literature on determinants that contribute towards the improvement in the environmental management system are presented in Table 1.

Table 1. Determinants aimed at the improvement of the environmental management system

\begin{tabular}{|c|c|}
\hline List of factors & Author \\
\hline $\begin{array}{l}\text { - the vision by the top management of environmental actions } \\
\text { provides essential resources to achieve the vision }\end{array}$ & Newman, Breeden (1992) \\
\hline - the engagement into the implementation of EMAS & $\begin{array}{l}\text { Heras-Saizarbitoria et al. } \\
\text { (2015); Testa et al. }(2014)\end{array}$ \\
\hline $\begin{array}{l}\text { - strong internal motivation } \\
\text { - the commitment of the top management } \\
\text { - the communication with stakeholder groups } \\
\text { - stakeholder involvement } \\
\text { - well-defined responsibilities for the environmental } \\
\text { management } \\
\text { - training and educational programmes }\end{array}$ & De Vries et al. (2012) \\
\hline - expectations of stakeholders & Zobel (2013) \\
\hline $\begin{array}{l}\text { - external environmental audits (requirements of the } \\
\text { certification body) }\end{array}$ & $\begin{array}{l}\text { Heras-Saizarbitoria } \\
\text { et al. }(2013)\end{array}$ \\
\hline - complementary standards such as ISO 9001 & Neugebauer (2012) \\
\hline - the commitment of top and middle management & Zutshi, Sohal (2004) \\
\hline $\begin{array}{l}\text { - the commitment to the leading role played by the top } \\
\text { management } \\
\text { - staff participation } \\
\text { - the evaluation of the management system by measurements } \\
\text { and internal audits }\end{array}$ & Badri et al. (1995) \\
\hline $\begin{array}{l}\text { - the introduction and development of the environmental } \\
\text { strategy } \\
\text { - environmental awareness of management } \\
\text { - the development of environmental awareness among staff } \\
\text { - the system approach to environmental solutions in designing } \\
\text { and developing a product } \\
\text { - evaluation of a life cycle, recycling } \\
\text { - redesigning of a product to decrease the amount of waste }\end{array}$ & $\begin{array}{l}\text { Epstein (1995) } \\
\text { Epstein, Wisner (2005) }\end{array}$ \\
\hline
\end{tabular}


End of Table 1

\begin{tabular}{|c|c|}
\hline List of factors & Author \\
\hline $\begin{array}{l}\text { - conducting environmental measurements aimed at factor } \\
\text { analysis and periodic environmental audits } \\
\text { - ensuring that the rule is clearly present in the continuous } \\
\text { strategy improvement of the entire organisation } \\
\text { - long-term technical and flotation environmental standards }\end{array}$ & $\begin{array}{l}\text { Brouwer, (Kris) van } \\
\text { Koppen }(2008)\end{array}$ \\
\hline $\begin{array}{l}\text { - aiming the business activity of an organisation and the } \\
\text { complete supply chain at the environment }\end{array}$ & Chen (2005) \\
\hline - management review & $\begin{array}{l}\text { Brouwer, (Kris) van } \\
\text { Koppen (2008) }\end{array}$ \\
\hline $\begin{array}{l}\text { - market requirements and competition pressure } \\
\text { - technical or technological possibilities of an organisation } \\
\text { - financial resources of an organisation applying an } \\
\text { assessment of a system according to the ISO } 14031 \text { standard } \\
\text { - using labels and environmental declarations according to } \\
\text { the ISO } 14020 \text { standard } \\
\text { - Implementing an evaluation of the life-cycle assessment in } \\
\text { accordance with the ISO } 14040 \text { standard }\end{array}$ & Matuszak-Flejszman (2011) \\
\hline $\begin{array}{l}\text { - targeting the improvement processes of environmental } \\
\text { management at managing human resources (motivation, } \\
\text { involvement) }\end{array}$ & Jabbour et al. (2008) \\
\hline
\end{tabular}

Source: elaboration by the authors based on the literature review.

A number of factors that contribute to the improvement of the environmental management system were discernible in the literature (Table 1). These factors result from both an organisation's internal activity, as well its external surroundings.

Despite numerous publications concerning the factors (internal and external) of the improvement of environmental management systems ISO 14001, a significant research gap is the lack of a detailed analysis of the existing relationship between the factors that determine the EMS improvement processes and their classification. In spite of being developed based on Polish experiences, the classification of the factors of the improvement process proposed by the authors can be used for the improvement of organisations based in other countries as well.

A constantly growing number of ISO 14001 certificates in Poland, reflecting the interest of individual organisations, is also reflected in the interest in these problems on the part of the researchers. Since 1998, when the first Polish company implemented and received ISO 14001 certificate, more than 2220 local facilities attained the certification up to 2013 (date from www.iso.org). Although the main premise of this research is to contribute to the knowledge on the effective functioning of ISO 14001 in the context of Poland, the results will have implications for ISO 14001 in other emerging economies. The network analysis and structural analysis were then applied to the above-enumerated factors with the aim of identifying the ones that are crucial to the improvement of the environmental management system. 


\section{Methods}

Structural analysis is a tool that structures the pooling of ideas. It is a system that utilises a matrix that combines the constituent components of the system. This method identifies the core variables that are both influential and dependent, i.e. those that are essential to the evolution of the system. Moreover, the structural analysis is a tool that enables the ordering and analysing of sets of structures, including a large number of variables, which are also known as factors and exert an influence on one another. By analysing dependencies between ostensibly irrelevant factors, the structural analysis method allows researchers to describe a mutual impact, as well as reaction. Based on these reactions, it is possible to distinguish the most important variables (Godet, Durance 2008; Arcade et al. 1994; Baležentis et al. 2010). Application of the structural analysis to each pair of A and B factors yields answers to the following questions: (i) does the A-factor have a direct impact on the B-factor? (ii) If so, is this impact small, medium, or crucial?

The structural analysis in the area of environmental management has so far been used, for example, to examine the relationship between the key practices of TQM and KM (Keng-Boon 2014), to analyse the relationship between the different components of the environmental responsibility (Gallardo-Vázquez, Sánchez-Hernández 2014).

The structural analysis can be conducted by utilizing the existing MICMAC computer software, created by M. Godet. The results yielded by the MICMAC software help to group variables and to identify variables that have the strongest influence on the entire system. The application of the MICMAC software allows to analyse complex systems whose functioning depends upon various driving forces. This then allows to simplify the system by identifying the crucial factors.

The algorithm used in the MICMAC software is based on three fundamental stages (Fig. 2):

Stage 1: Determining factors that have an influence on the given occurrence.

Stage 2: Describing relations between factors by building a matrix and drawing a direct and indirect impact graph.

Stage 3: Identifying groups of factors including crucial factors and drawing the influence-dependence chart (Ahmed et al. 2009).

Stage 1. The described process begins with establishing all internal and external variables that are characteristic of a given occurrence with a view to creating a system of interrelated dynamic elements. Among the methods to identify factors that have an influence on the environmental management system (ISO 14001) were a literature review and an expert panel.

Stage 2. When variables are established, an influence-dependence model is created. The matrix of direct impact allows to identify the relationship between factors that exert an influence on the research subject. The influence of the factors is often graded according to the three-stage scale: 0 meaning no influence; 1 - a small influence; 2 - a medium influence (essential, but not crucial); 3 - a crucial influence. An exemplary matrix is shown in Table 2. 


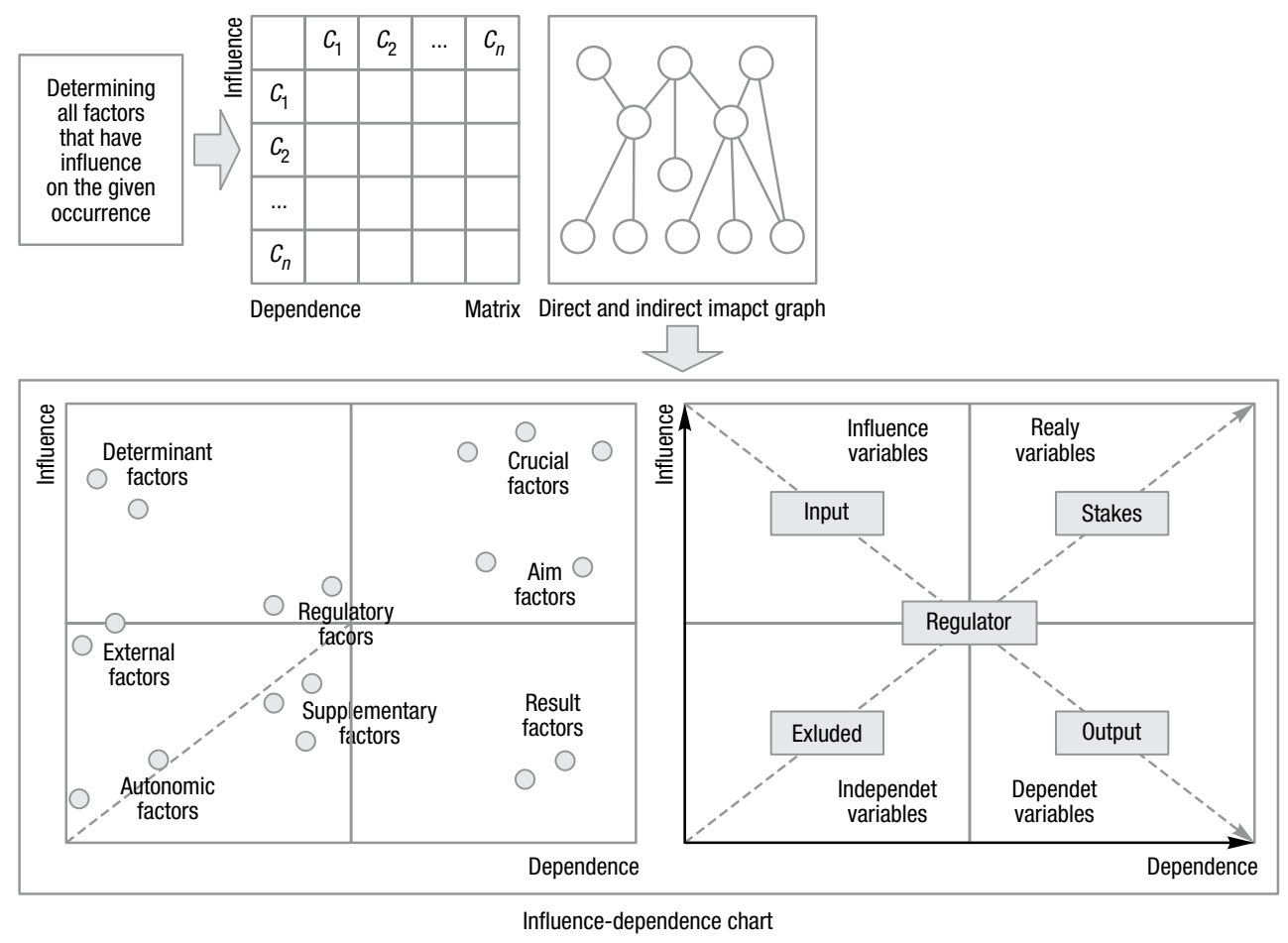

Fig. 2. Flow diagram of the research process

Table 2. Example of a matrix used for the structural analysis

\begin{tabular}{|c|c|c|c|}
\hline Itemisation & $\begin{array}{c}\text { Factor } 1 \\
S c_{1}\end{array}$ & $\begin{array}{c}\text { Factor } 2 \\
\mathrm{Sc}_{2}\end{array}$ & $\begin{array}{c}\text { Factor N } \\
S c_{n}\end{array}$ \\
\hline Factor $1 S c_{1}$ & $c_{11}$ & $c_{12}$ & $c_{1 n}$ \\
\hline Factor $2 S c_{2}$ & $c_{21}$ & $c_{22}$ & $c_{2 n}$ \\
\hline$\ldots \ldots \ldots \ldots \ldots \ldots$ & $\ldots$ & $\ldots$ & $\ldots$ \\
\hline Factor $\mathrm{N} S c_{\mathrm{n}}$ & $c_{n 1}$ & $c_{n 2}$ & $c_{n n}$ \\
\hline
\end{tabular}

The strength of the structural analysis lies in its ability to identify relations among variables (Nazarko et al. 2011). A mutual influence among variables is not readily discernible and can even be unrecognisable by experts in a given branch of science.

The essential stage of the MICMAC methodology is that of the identification of crucial factors. MICMAC software depicts the force of direct as well as indirect relationships between factors, based on a predefined matrix of the indirect impact. The direct matrix of impact is then transformed into a graph, in which vertices correspond to the given factors. Next, in order to determine the degree of influence of each factor on the remaining factors, it is crucial to determine the number of paths and loops extending out from the graph vertex and corresponding to the factor in question. The strength of dependen- 
cies of the factor on other factors is made clear by determining the number of paths and loops going into the vertex of the graph corresponding to the factor. The indirect influence between the factors is elucidated by the consecutive raising to a power of the direct influence matrix, which allows researchers to determine the occurrence of the loop with the length described by the exponentiation of the matrix.

Stage 3. Identifying groups of factors. The MICMAC software enables us to present the results on the two-dimensional surface described by the coordinates, corresponding to the strength of influence and the strength of dependencies of the individual variables. The analysis of the distribution of individual factors on the two-dimensional influencedependency surface allows us to determine their role in the system (Godet, Durance 2011).

The structural analysis allows distinguishing the factors that impact on a given research area: crucial factors, which are characterized by a large-scale impact and a high degree of dependency on other factors, and due to high instability, these factors require a critical scrutiny; aim factors, are dependent on other factors and tend to be influenced by such factors rather than vice versa; result factors are characterized by a low impact and high dependency on other factors and are especially susceptible to changes in the crucial factors; determinant factors have a strong impact on the system and are characterised by a low level of dependency on other factors, and can be regarded as a driving or braking force; regulatory and supplementary factors are characterised by a minimal impact on the system and can prove to be beneficial in achieving strategic goals; external factors are characterised by having a relatively smaller impact on the system than determinant factors, but a greater impact than autonomic variables, and are not impacted upon by other variables; autonomic factors are characterised by exerting the least impact on changes taking place in the system as a whole unit (Godet, Durance 2011; Lee et al. 2010; Mazurkiewicz, Poteralska 2009; Popper 2003; Wójcicki, Ładyżyński 2008). An example of factor classification is given in Figure 3.

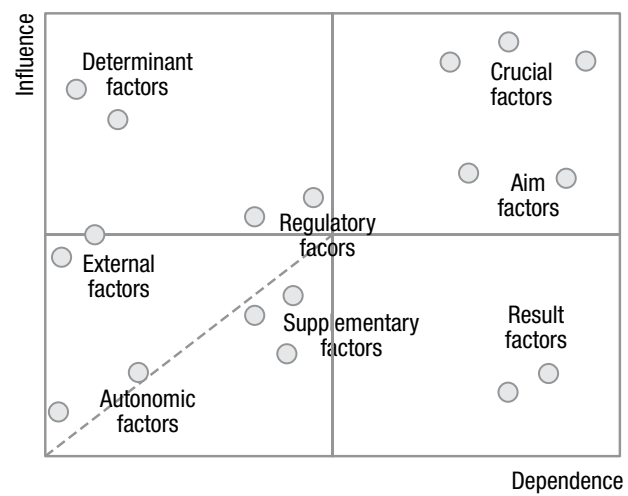

Fig. 3. Arrangement of factors having an impact on a given research area an example of a result of the structural analysis

Source: Nazarko, Kędzior (2010). 
In this research study, a structural analysis was conducted in three stages:

- creating a list of factors that impact on the improvement of the functioning of the environmental management system ISO 14001;

- establishing a force of interaction between identified factors;

- identifying crucial variables through the use of MICMAC software ver. 6.1.3.

\section{Results}

\subsection{List of determinants}

The list of wide range of factors determining the effectiveness of the improvement processes aimed at the ISO environmental management systems started with a literature review. Subsequently, the qualitative research method was used, which involved the participation of environmental management experts. The experts involved were consultants experienced in auditing and implementation of ISO standards (not limited to ISO 14001), and three university professors teaching and researching environmental management systems. As a result of the work of the expert panel, which was organised in the fourth quarter of 2013, fifteen factors were identified as important from the perspective of the EMS improvement processes and were used for further analysis. These determinants are enumerated below:

1. The strategy of the organisation.

2. The commitment of the top management.

3. Functioning and/or implementation of other management systems (quality, health and safety).

4. The participation of the organisation in systems or environmental programmes, e.g. EMAS, Cleaner Production.

5. Opinions, results and complaints of interested parties.

6. Market requirements and competition pressure.

7. Technical or technological possibilities of the organisation.

8. Financial resources of the organisation.

9. Motivation, involvement and staff awareness.

10. Applying an assessment system according to the ISO 14031 standard.

11. Using labels and environmental declarations according to the ISO 14020 standard.

12. Implementing an evaluation of the life-cycle assessment in accordance with the ISO 14040 standard.

13. Internal audits.

14. Certification body requirements.

15. Management review.

Then, according to the adopted methodology of the applied structural analysis, experts evaluated the force of interaction between the identified 15 factors. To this end, they were asked to complete the matrix enabling the evaluation of the impact force of individual factors on other factors. 


\subsection{Direct impact matrix}

A direct impact matrix was created on the basis of a direct influence matrix, which was individually filled in by experts.

Each of the surveyed experts graded the impact of individual factors by employing the following scale: 0 meaning no impact; 1 - a small impact; 2 - a medium impact (crucial, but not essential); 3 - a crucial impact. The direct impact matrix included the factors that were most frequently cited by the experts.

The resultant direct impact matrix of the improvement of the environmental management system is depicted in Figure 4.

\begin{tabular}{|c|c|c|c|c|c|c|c|c|c|c|c|c|c|c|c|}
\hline & $\begin{array}{l}\text { 总 } \\
\text { 荧 } \\
\frac{\omega}{\omega}\end{array}$ & 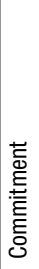 & 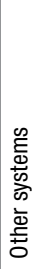 & 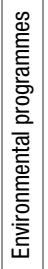 & 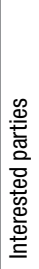 & 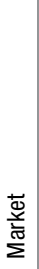 & 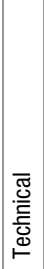 & 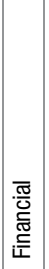 & 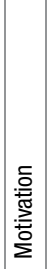 & $\begin{array}{l}\overline{\mathfrak{m}} \\
\dot{\sigma} \\
\underline{\delta} \\
\underline{0}\end{array}$ & 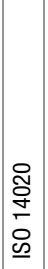 & 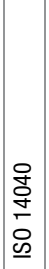 & 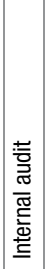 & 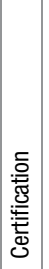 & 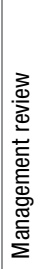 \\
\hline Strategy & 0 & 2 & 1 & 1 & 1 & 3 & 2 & 3 & 1 & 1 & 1 & 1 & 1 & 0 & 2 \\
\hline Commitment & 3 & 0 & 3 & 3 & 1 & 2 & 2 & 2 & 3 & 3 & 2 & 1 & 2 & 0 & 3 \\
\hline Other systems & 2 & 3 & 0 & 2 & 2 & 2 & 2 & 1 & 2 & 0 & 1 & 1 & 3 & 0 & 3 \\
\hline Environmental programmes & 1 & 1 & 2 & 0 & 1 & 2 & 1 & 1 & 2 & 3 & 1 & 2 & 2 & 1 & 1 \\
\hline Interested parties & 2 & 1 & 1 & 1 & 0 & 1 & 0 & 0 & 0 & 1 & 1 & 1 & 2 & 0 & 2 \\
\hline Market & 3 & 2 & 2 & 2 & 2 & 0 & 0 & 2 & 1 & 2 & 2 & 1 & 1 & 0 & 1 \\
\hline Technical & 3 & 2 & 2 & 2 & 2 & 2 & 0 & 3 & 2 & 1 & 1 & 1 & 1 & 1 & 0 \\
\hline Financial & 3 & 3 & 2 & 1 & 1 & 1 & 3 & 0 & 2 & 2 & 1 & 1 & 1 & 0 & 2 \\
\hline Motivation & 1 & 2 & 2 & 1 & 2 & 2 & 1 & 2 & 0 & 1 & 1 & 1 & 2 & 1 & 2 \\
\hline ISO 14031 & 2 & 2 & 1 & 0 & 2 & 1 & 2 & 2 & 1 & 0 & 0 & 2 & 2 & 1 & 3 \\
\hline ISO 14020 & 3 & 1 & 0 & 3 & 1 & 0 & 1 & 2 & 1 & 1 & 0 & 2 & 1 & 2 & 2 \\
\hline ISO 14040 & 2 & 2 & 1 & 2 & 1 & 1 & 2 & 1 & 0 & 2 & 2 & 0 & 1 & 0 & 1 \\
\hline Internal audit & 1 & 2 & 2 & 1 & 2 & 1 & 2 & 1 & 2 & 1 & 1 & 1 & 0 & 3 & 3 \\
\hline Certification & 1 & 2 & 2 & 0 & 0 & 0 & 0 & 0 & 1 & 1 & 1 & 1 & 1 & 0 & 2 \\
\hline Management review & 3 & 3 & 2 & 1 & 2 & 1 & 1 & 1 & 2 & 1 & 1 & 1 & 3 & 0 & 0 \\
\hline
\end{tabular}

Legend: 0 - no impact; 1 - a small impact; 2 - a medium impact; 3 - a crucial impact.

Fig. 4. Impact strength of the fifteen factors

Source: research by the authors conducted using MICMAC software ver. 6.1.3.

Taking into account the assessment of the reliability of the scale used in this study, Cronbach's alpha coefficients for the 15 scales corresponding to the examined areas (Sc1-Sc15, Table 3) were calculated. In this approach, it was assumed that the measurement scales were separable, and the responses given by the respondents in the ordinal scales answered subsequent research questions. The results of the scale reliability analysis lead us to the conclusion that the scales adopted in the study were correct (Cronbach's alpha of no less than 0.8 in $80 \%$ of cases). It means that further measurements adopting such a scale allow to obtain insignificantly different results.

The characteristics of the basic properties of the direct impact matrix are presented in Table 4. 
Table 3. Cronbach's alpha coefficients obtained in the scale reliability analysis

\begin{tabular}{cccccc}
\hline Scale ID & $\begin{array}{c}\text { Cronbach's } \\
\text { alpha }\end{array}$ & Scale ID & $\begin{array}{c}\text { Cronbach's } \\
\text { alpha }\end{array}$ & Scale ID & $\begin{array}{c}\text { Cronbach's } \\
\text { alpha }\end{array}$ \\
\hline Sc1 & 0.818 & Sc6 & 0.934 & Sc11 & 0.900 \\
\hline Sc2 & 0.825 & Sc7 & 0.822 & Sc12 & 0.913 \\
\hline Sc3 & 0.799 & Sc8 & 0.868 & Sc13 & 0.825 \\
\hline Sc4 & 0.733 & Sc9 & 0.701 & Sc14 & 0.909 \\
\hline Sc5 & 0.852 & Sc10 & 0.888 & Sc15 & 0.815 \\
\hline & Max & 0.934 & \multicolumn{3}{c}{ Min } \\
\hline
\end{tabular}

Source: calculations by the authors using Statistica PL.

Table 4. Characteristics of the direct impact matrix

\begin{tabular}{ll}
\hline \multicolumn{1}{c}{ Indicator } & Value \\
\hline Matrix size & 15 \\
\hline Number of zeros (no impact ) & 37 \\
\hline Number of ones (a small impact ) & 91 \\
\hline Number of twos (a medium impact ) & 69 \\
\hline Number of threes (a crucial impact) & 28 \\
\hline Degree of completion & $83.6 \%$ \\
\hline
\end{tabular}

Source: research by the authors.

In 37 instances, the dominant value was 0 , indicating that there was no relationship between these factors; in 91 instances, slight dependencies were found; in 69 instances, a medium impact was discovered; and in 28 instances, crucial dependencies were discovered. Values other than 0 were present in $83.6 \%$ of the fields indicating that the experts identified many more dependencies than in previous analyses; on average, the degree of completion was approx. 20\% (Wójcicki, Ładyżyński 2008).

\subsection{Total impact strength and the strongest direct impact between the factors}

The total strength of impact determined among the fifteen factors is presented in Table 5. The results clearly indicate that the following factors have a strong direct impact: the involvement of, and the leading role conducted by the top management; the presence of a variety of management systems in an organisation; external audits and management review. The factors that have the least impact on the remaining elements, including the following: certification body requirements and opinions and complaints of stakeholders. These factors are external in nature.

The factors and elements that receive the greatest impact by other factors include: the strategy of an enterprise; the involvement of, and the leading role conducted by the top management; as well as the management review. Conversely, the factor that receives the least impact is the certification body requirements. 
Table 5. Total strength of direct impact occurring between the structural analysis factors

\begin{tabular}{|c|c|c|c|}
\hline No. & Factor & $\begin{array}{l}\text { Quantity of } \\
\text { impact }\end{array}$ & $\begin{array}{c}\text { Number of } \\
\text { dependencies }\end{array}$ \\
\hline Sc 1 & The strategy of the organisation (Strategy) & 20 & 31 \\
\hline Sc 2 & The commitment of the top management (Commitment) & 30 & 27 \\
\hline Sc 3 & $\begin{array}{l}\text { Functioning and/or implementation of other management } \\
\text { systems (quality, health and safety) (Other systems) }\end{array}$ & 26 & 24 \\
\hline $\operatorname{Sc} 4$ & $\begin{array}{l}\text { Organising participation in stems or environmental } \\
\text { programmes e.g. EMAS, Cleaner Production } \\
\text { (Environmental programmes) }\end{array}$ & 21 & 23 \\
\hline Sc 5 & $\begin{array}{l}\text { Opinions, results, complaints of stakeholders } \\
\text { (Stakeholders) }\end{array}$ & 13 & 18 \\
\hline Sc 6 & $\begin{array}{l}\text { Market requirements and pressure of competitors } \\
\text { (Market) }\end{array}$ & 21 & 18 \\
\hline Sc 7 & $\begin{array}{l}\text { Technical or technological possibilities of the } \\
\text { organisation (Technical) }\end{array}$ & 23 & 19 \\
\hline Sc 8 & Financial resources of the organisation (Financial) & 23 & 21 \\
\hline Sc 9 & $\begin{array}{l}\text { Motivation, involvement, and staff awareness } \\
\text { (Motivation) }\end{array}$ & 21 & 20 \\
\hline Sc 10 & $\begin{array}{l}\text { Application of an assessment system according to the } \\
\text { ISO } 14031 \text { norm (ISO 14031) }\end{array}$ & 20 & 20 \\
\hline Sc 11 & $\begin{array}{l}\text { Using labels and environmental declarations in } \\
\text { accordance with ISO } 14020 \text { standards (ISO 14020) }\end{array}$ & 17 & 16 \\
\hline Sc 12 & $\begin{array}{l}\text { Implementing evaluation of the life cycle in accordance } \\
\text { with ISO } 14040 \text { standards (ISO 14040) }\end{array}$ & 18 & 17 \\
\hline Sc 13 & Internal audits (Internal audit) & 24 & 23 \\
\hline Sc 14 & Certification body requirements (Certification) & 12 & 9 \\
\hline \multirow[t]{2}{*}{ Sc 15} & Management review (Management review) & 24 & 27 \\
\hline & Total & 313 & 313 \\
\hline
\end{tabular}

Source: research by the authors based on MICMAC software ver. 6.1.3.

Within the framework of the analysis conducted, a graph presenting the direct factor impact was created using the PAJEK software (Fig. 5).

Figure 4 constitutes a graphical representation of the impact individual factors have on one another. The arrows indicate the direction of the impact and the line congestion in the field of the selected factors presents either those factors that receive the greatest impact, or those that exert the greatest impact on other factors. These include: management commitment, the strategy of the organisation, and management review. 


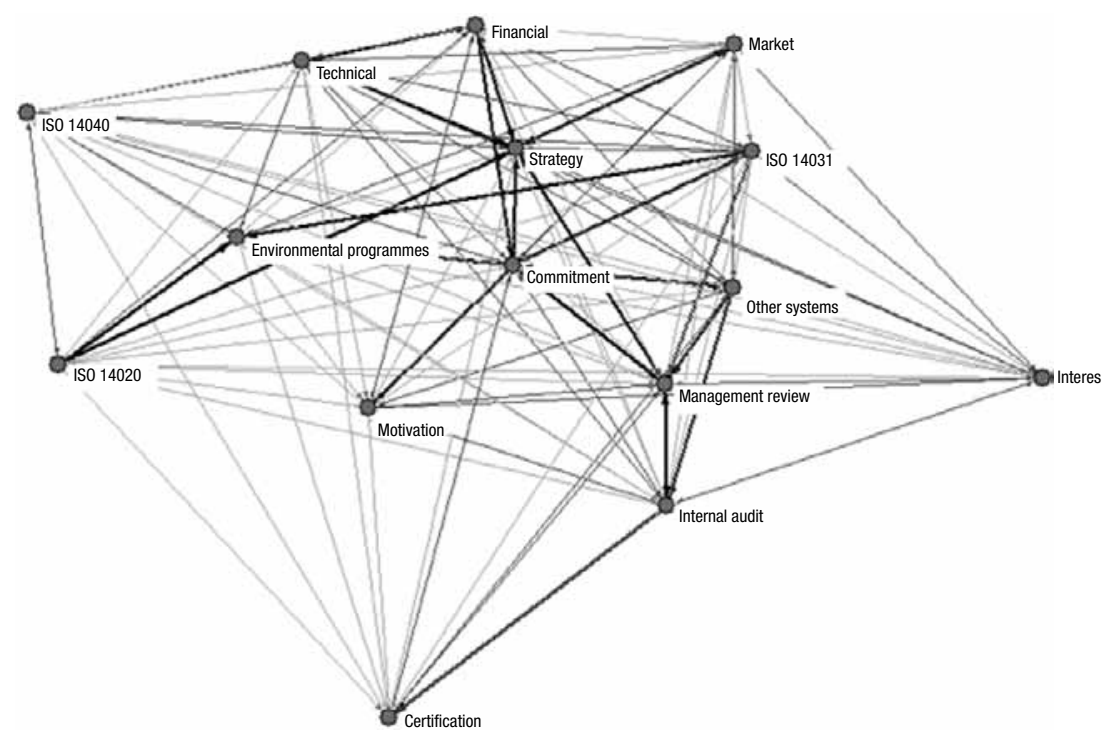

Fig. 5. Direct impact graph

Source: research by the authors using PAJEK software ver. 4.01.

\subsection{Factor classification of the structural analysis based on the direct impact}

The layout of the structural analysis factors on a two-dimensional surface depicting impact-dependency is presented in Figure 6. In accordance with the MICMAC methodology, some characteristic feature groups were distinguished.

From the structural analysis into factors impacting on the improvement of the environmental management system, five groups of factors can be discerned: (i) crucial factors, (ii) aim factors, (iii) supplementary factors, (iv) regulatory factors and (v) autonomous (independent) Factors. The authors didn't limit the number of groups, but the conducted research resulted only in five groups of factors.

Crucial factors or factors that exert the greatest impact on the improvement of the environmental management system, include the following:

- the commitment of the top management;

- functioning and/or implementation of other management systems (quality, health and safety);

- internal audits;

- management reviews.

The strategic activity of an organisation was included in the 'aims' group, which indicates that it is a fairly dependent factor that exerts a medium impact on the remaining factors. According to the results, experts involved in the project thought the environmental management system exerted an impact on an organisation's strategy rather than vice versa. This means that the strategy reflects an incommensurate need for the improvement of the system. 


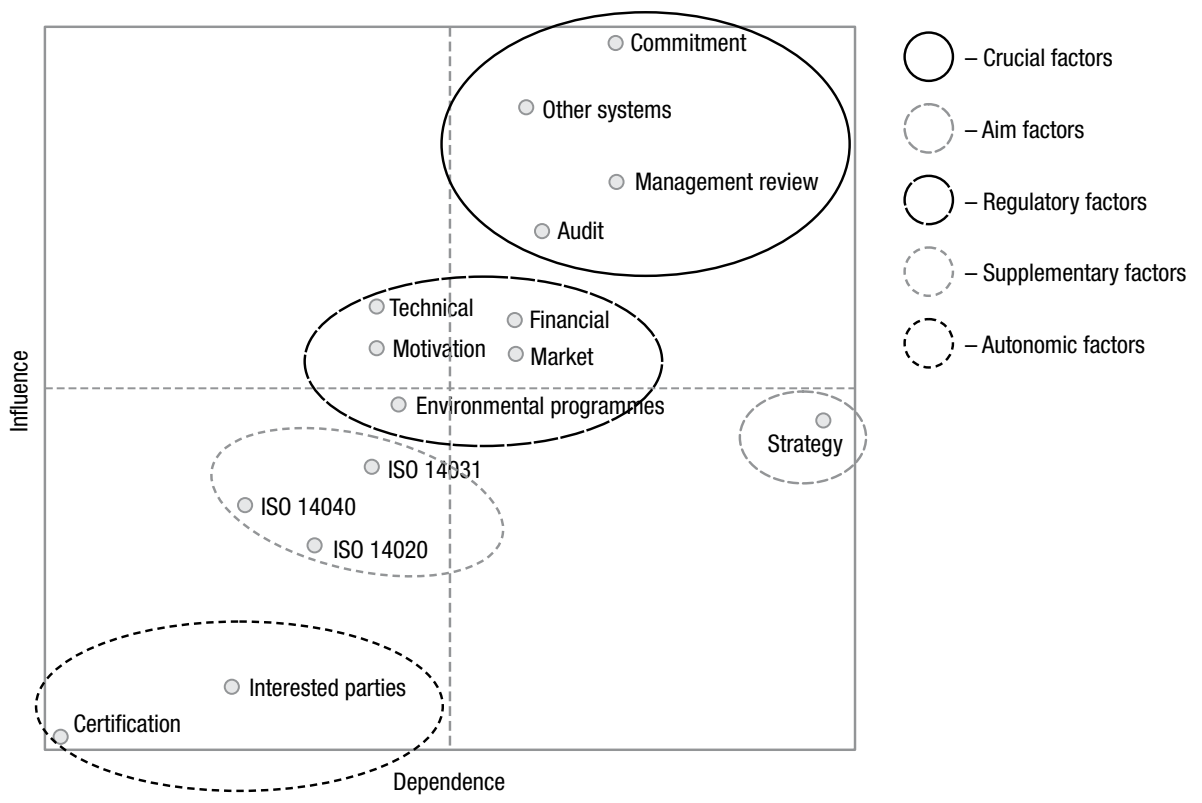

Fig. 6. Structural analysis division of factors based on the direct impact Source: research by the authors using MICMAC software ver. 6.1.3.

The following factors are average-dependent and exert an average impact on the remaining factors; therefore, they can be classified as regulatory factors:

- technical or technological possibilities of the organisation;

- financial resources of the enterprise;

- motivation, involvement, and staff awareness;

- organisation participation in systems or environmental programmes etc. EMAS;

- market requirements and competitors pressure.

This group of factors includes the determinants of internal and external nature. The factors of internal nature included the factors related to the provision of adequate resources, both technical and technological, financial, as well as human resources related to the provision of adequate staff motivation, commitment and raising the awareness of employees. In the process of improving the environmental management systems, the requirements of the market and competitive pressures play an important role among the regulatory factors. The dynamics of changes in the environment, which is the result of the increasing volatility and complexity of the environment, force the organisations with certified ISO environmental management systems to conduct improvement measures.

Another group of factors determining the processes of improving environmental management system ISO 14001 involves supplementary factors which include:

- the application of an assessment system in accordance with the ISO 14031 standard;

- the use of labels and environmental declarations in accordance with the ISO 14020 standard; 
- the implementation of an evaluation of the life cycle in accordance with the ISO 14040 standard.

This group of factors includes utility standards ISO 14031, ISO 14020 and ISO 14040, which constitute guidelines for the improvement of individual elements of the environmental management system. These standards define the general assumptions in terms of measuring environmental performance (ISO 14031), the use of eco-labelling (ISO 14020) and the evaluation throughout the life cycle (ISO 14040). The obtained results confirmed that an essential element for the improvement of the environmental management system is the guidelines laid down in the utility standards mentioned above.

The fifth group that constitutes the autonomous factors, i.e. factors that have the smallest impact on the improvement of the environmental management system, includes:

- certification body requirements;

- opinions, applications, complaints of the interested parties.

\section{Discussion of the results}

The obtained results are consistent with the results received by other researchers indicating a strong relationship between the achieved positive results of the environmental management system improvement with the top and middle management commitment (Heras-Saizarbitoria 2011; Zutshi, Sohal 2004).

In the group of identified crucial factors, there are factors that indicate the functioning of other systems, such as, high-quality management or health and safety systems, which are also crucial to continuous improvement. The implementation and functioning of integrated systems within an organisation are sufficient evidence that these systems have proven to be beneficial to organisations. Similar results were found in a more recent study, the data of which indicated that manufacturing facilities with certified EMSs in seven OECD countries are more likely to have a variety of other environmental management tools in place (Johnstone, Labonne 2009). Having additional management systems in place can also lead to the improvement of the environmental management system. It is significantly easier to improve an integrated management system associated with the management culture of an organisation. In such a system, an organisation has greater possibilities, for instance, it can combine the objectives of its various management systems. However, this depends on the approach of the personnel responsible for the integrated management system. In the course of integration, various management systems of an organisation can produce a synergistic effect (Salomone 2008; Hamidi et al. 2012; Simon et al. 2012).

The results of conducted studies have proven that in addition to audits, management reviews also constitute a crucial factor in the improvement of the environmental management system. It is essential that reviews of the management policy are carried out at the level of the top management of a particular organisation. As they have a strategic character, only the personnel involved in the development of the organisation can observe the inconsistencies between presuppositions of the current plan and strategic plans. 
One of the identified factors from the group of regulatory factors, which determine improvement processes, is the involvement of the organisation in other systems and environmental programmes, such as EMAS. A research conducted by Testa et al. (2014) also confirmed that the adoption of ISO 14001 seems to be accompanied by greater improvements in environmental performance in the short term than in the long term. As a consequence, the maturity of an ISO 14001 certification is not regularly coupled with a strong improvement in environmental performance (Testa et al. 2014). On the contrary, implementation of EMAS by organisations lead to a process that is strongly influenced by the involvement of competent authorities in verification phases. This results in both an opportunity for developing transparent and collaborative relationships with relevant public and private stakeholders and a stronger pressure towards tangible and continuous improvements in the environmental performance.

The obtained results also confirmed that the requirements of the certification bodies (Certification) included in the group of autonomous factors, do not constitute a prerequisite for organisations with environmental management systems to improve the systems. Certification bodies are often more interested in the assessment and verification of compliance of the system with the requirements of the standard, than the actual improvement process. Similar results were obtained by Heras-Saizarbitoria et al. (2013), indicating that certification audits, far from preventing the superficial adoption of the ISO 14001 standard, contribute to the spread of procedural environmental practices that emphasise paperwork rather than internal efficiency.

\section{Conclusions}

The conducted study is an example of the application of the structural analysis for the purpose of the classification of the factors determining the improvement processes in an organisation with ISO 14001 certified environmental management systems. They extend the current area of interest, which was mainly focused on the identification of the factors of improvement without the analysis of the relationships occurring between them.

The structural analysis demonstrates that the involvement of, and the leading role played by the top management serves as a crucial factor in the improvement of the environmental management system. The results have proven that the 'top down' approach constitutes a crucial element in improving management systems, as the involvement of the top level management that demonstrates the wanted attitude ensures the involvement of other staff members and motivates them for continuous improvement.

In summary, the research presented in this article offers three types of first-hand, practical applications of the method and findings. Firstly, to the academic community it presents the application of the structural analysis to the study of environmental managements systems. Secondly, to the companies who either consider or have already implemented the system, the research findings show the most important elements needed to achieve the best results from the investment in the system. Thirdly, to the external auditors and ISO consulting community, the article supports their earlier practical experience with ISO 14001 with academically tested arguments on what areas of the system implementation should require additional support in order to bring the best result to the company. 


\section{Limitations and further research}

As in most other studies, the results presented in the article can be interpreted taking into account some limitations.

The first research limitation is its national character, which makes it impossible to carry out comparative studies in an international system. However, focusing the studies on the national context has enabled us to gain new knowledge concerning the applicability of the structural analysis for the classification of the EMS improvement factors.

Consequently, the second limitation of this study was the limitation of the perspective of the conducted analyses to a group of experts with qualifications, knowledge and experience in the implementation and certification of environmental management systems. The potential area of research interests in the future may be the analysis of the factors determining the processes of improvement of ISO 14001 environmental management systems, conducted from the perspective of units possessing these systems. This type of study would allow for the subsequent conduct of a comparative analysis for the two groups.

The third limitation is that in the case of structural analysis used in this research, input data is of the subjective nature, specifically the list of variables enumerated during the first phase of the research and the relationships among those variables determined by a team of experts in a given field.

Future research could search for the existing links and classification of factors determining the improvement of the environmental management system from the perspective of organisations possessing these systems, and on the other hand, the extension of the scope of the study with the international context allowing for a further analysis of the causes of variation of the results obtained in individual countries (Mariotti et al. 2014).

\section{References}

Ahmed, M. T.; Saleh, M.; Abdelrehim, A. 2009. El Maghara scenario a search for sustainability and equity: an Egyptian case study, Journal of Futures Studies 14(2): 55-89 [online], [cited 10 October 2014]. Available from Internet: http://www.jfs.tku.edu.tw/wp-content/uploads/2014/01/142A04.pdf

Arcade, J.; Godet, M.; Meunier, F.; Roubelat, F. 1994. Structural analysis with the MICMAC method \& Actors'strategy with Mactor method. AC/UNU Millennium Project Futures Research Methodology, Paris [online], [cited 1 November 2014]. Available from Internet: http://www. lampsacus.com/documents/MICMACMETHOD.pdf

Badri, M. A.; Davis, D.; Davis, D. 1995. A study of measuring the crucial factors of quality management, International Journal of Quality \& Reliability Management 12(2): 36-53.

http://dx.doi.org/10.1108/02656719510080604

Baležentis, A.; Baležentis, T.; Valkauskas, R. 2010. Evaluating situation of Lithuania in the European Union: structural indicators and MULTIMOORA method, Technological and Economic Development of Economy 16(4): 578-602. http://dx.doi.org/10.3846/tede.2010.36

Berliner, D.; Prakash, A. 2013. Signaling environmental stewardship in the shadow of weak governance: the global diffusion of ISO 14001, Law \& Society Review 47(2): 345-373.

http://dx.doi.org/10.1111/lasr.12015 
Boiral, O.; Henri J. F. 2012. Modelling the impact of ISO 14001 on environmental performance: a comparative approach, Journal of Environmental Management 99: 84-97.

http://dx.doi.org/10.1016/j.jenvman.2012.01.007

Brouwer, M. 2004. Continue verbetering in ISO 14001: meten of vergeten? Wageningen: Wageningen University [online], [cited 15 September 2014]. Available from Internet: http://brandts. qualityportal.nl/media/17064/Thesis_ISO14001_universiteit_Wageningen.pdf

Brouwer, M. A. C.; (Kris) van Koppen, C. S. A. 2008. The soul of the machine: continuous improvement in ISO 14001, Journal of Cleaner Production 16(4): 450-457.

http://dx.doi.org/10.1016/j.jclepro.2006.08.022

Chen, C. 2005. Incorporating green purchasing into the frame of ISO 14000, Journal of Cleaner Production 13(9): 927-933. http://dx.doi.org/10.1016/j.jclepro.2004.04.005

Ciegis, R.; Streimikiene, D.; Zavadskas, E. K. 2008. The use of the environmental Kuznets curve: environmental and economic implications, International Journal of Environment and Pollution 33(2-3): 313-335. http://dx.doi.org/10.1504/IJEP.2008.019401

Comogli, C.; Serena, B. 2012. The use of indicators and the role of environmental management systems for environmental performances improvement: a survey on ISO 14001 certified companies in the automotive sector, Journal of Cleaner Production 20: 92-102.

http://dx.doi.org/10.1016/j.jclepro.2011.08.022

De Jong, P.; Paulraj, A.; Blome, C. 2014. The financial impact of ISO 14001 certification: topline, bottom-line, or both?, Journal of Business Ethics 119(1): 131-149.

http://dx.doi.org/10.1007/s10551-012-1604-z

De Oliveira Baumbach, M.; do Prado Filho, J. F.; Fonseca, A. 2013. Environmental management in small mining enterprises: comparative analysis of three Brazilian cases through the lenses of ISO 14001, Rem-Revista Escola de Minas 66(1): 111-116.

http://dx.doi.org/10.1590/S0370-44672013000100015

De Vries, H. J.; Bayramoglu, D. K.; van der Wiele, T. 2012. Business and environmental impact of ISO 14001, International Journal of Quality \& Reliability Management 29(4): 425-435.

http://dx.doi.org/10.1108/02656711211224866

Deming, W. E. 1986. Out of the crisis. Cambridge, MA: MIT Press.

Ejdys, J.; Matuszak-Flejszman, A. 2010. New management systems as an instrument of implementation sustainable development concept at organizational level, Technological and Economic Development of Economy 16(2): 202-218. http://dx.doi.org/10.3846/tede.2010.13

Epstein, M. J. 1995. Measuring corporate environmental performance: best practices for costing and managing an effective environmental strategy. McGraw-Hill Companies.

Epstein, M. J.; Wisner, P. S. 2005. Managing and controlling environmental performance: evidence from Mexico, Advances in Management Accounting 14: 115-137.

http://dx.doi.org/10.1016/S1474-7871(05)14005-2

Franchetti, M. 2011. ISO 14001 and solid waste generation rates in US manufacturing organizations an analysis of relationship, Journal of Cleaner Production 19(9-10): 1104-1109.

http://dx.doi.org/10.1016/j.jclepro.2011.01.004

Gallardo-Vázquez, D.; Sánchez-Hernández, M. I. 2014. Structural analysis of the strategic orientation to environmental protection in SMEs, Business Research Quarterly 17: 115-128.

Godet, M.; Durance, P. 2008. La prospective stratégique, pour les entreprises et les territoires. Paris: Dunod.

Godet, M.; Durance, P. 2011. Strategic foresight. For corporate and regional development. Paris: Dunod.

Gomez, A.; Rodriguez, M. A. 2011. The effect of ISO 14001 certification on toxic emissions: an analysis of industrial facilities in the north of Spain, Journal of Cleaner Production 19(9-10): 1091-1095. http://dx.doi.org/10.1016/j.jclepro.2011.01.012 
Granly, B. M.; Welo, T. 2014. EMS and sustainability: experiences with ISO 14001 and EcoLighthouse in Norwegian metal processing SMEs, Journal of Cleaner Production 64: 194-204. http://dx.doi.org/10.1016/j.jclepro.2013.08.007

Hamidi, N.; Omidvari, M.; Meftahi, M. 2012. The effect of integrated management system on safety and productivity indices: case study; Iranian cement industries, Safety Science 50(5): 1180-1189. http://dx.doi.org/10.1016/j.ssci.2012.01.004

Heras-Saizarbitoria, I. 2011. Internalization of ISO 9000: an exploratory study, Industrial Management and Data Systems 111(8): 1214-1237. http://dx.doi.org/10.1108/02635571111170776

Heras-Saizarbitoria, I.; Dogui, K.; Boiral, O. 2013. Shedding light on ISO 14001 certification audits, Journal of Cleaner Production 51: 88-98. http://dx.doi.org/10.1016/j.jclepro.2013.01.040

Heras-Saizarbitoria, I.; Arana, G.; Boiral, O. 2015. Exploring the dissemination of environmental certifications in high and low polluting industries, Journal of Cleaner Production 89: 50-58. http://dx.doi.org/10.1016/j.jclepro.2014.10.088

Heras-Saizarbitoria, I.; Boiral, O. 2013. ISO 9001 and ISO 14001: towards a research agenda on management system standards, International Journal of Management Reviews 15(1): 47-65. http://dx.doi.org/10.1111/j.1468-2370.2012.00334.x

Hwang, B. G.; Leong, L. P. 2013. Comparison of schedule delay and causal factors between traditional and green construction projects, Technological and Economic Development of Economy 19(2): 310-330. http://dx.doi.org/10.3846/20294913.2013.798596

ISO 14001: 2015. Environmental management systems - requirements with guidance for use. Final Draft. ISO, Geneva.

ISO 14004: 2004. Environmental management systems - general guidelines on principles, systems and support. ISO, Geneva.

ISO 14020: 2000. Environmental labels and declarations - general principles. ISO, Geneva.

ISO 14031:2013. Environmental management - environmental performance evaluation - guidelines. ISO, Geneva.

ISO 14040: 2006. Environmental management - life cycle assessment - principles and framework. ISO, Geneva.

ISO 9004: 2009. Managing for the sustained success of an organization. A quality management approach. ISO, Geneva.

Jabbour, C. J. C.; Santos, F. C. A.; Nagano, M. S. 2008. Environmental management system and human resource practices: is there a link between them in four Brazilian companies?, Journal of Cleaner Production 16(17): 1922-1925. http://dx.doi.org/10.1016/j.jclepro.2008.02.004

Johnstone, N.; Labonne, J. 2009. Why do manufacturing facilities introduce environmental management systems? Improving and/or signaling performance, Ecological Economics 68: 719-730. http://dx.doi.org/10.1016/j.ecolecon.2008.06.003

Junnila, S.; Ristimäki, M. 2012. Public demand for eco-efficient concepts in urban development, International Journal of Strategic Property Management 16(1): 21-36.

http://dx.doi.org/10.3846/1648715X.2011.609569

Keng-Boon, O. 2014. TQM: a facilitator to enhance knowledge management? A structural analysis, Expert Systems with Applications 41: 5167-5179.

http://dx.doi.org/10.1016/j.eswa.2014.03.013

Kim, Y. W.; Azari-N, R.; Yi, J. S.; Bae, J. 2013. Environmental impacts comparison between on-site vs. prefabricated Just-In-Time (prefab-JIT) rebar supply in construction projects, Journal of Civil Engineering and Management 19(5): 647-655. http://dx.doi.org 10.3846/13923730.2013.795186

Kobylińska, U. 2014. Ewolucja czy rewolucja? Zmiany w standardzie ISO 9001:2015 [Evolution or Revolution? The new ISO 9001:2015 standard], Economics and Management 6(1): 205-219. 
Lulewicz, A. 2013. Wpływ podejmowanych przez przedsiębiorstwa inicjatyw społecznie odpowiedzialnych na wartość organizacji [The impact of the socially responsible initiatives taken by the company on the value of the organization], Economics and Management 5(2): 242-254.

Lee, Y. C.; Chao, Y. H.; Lin, S. B. 2010. Structural approach to design user interface, Computers in Industry 61: 613-623. http://dx.doi.org/10.1016/j.compind.2010.01.003

Mariotti, F.; Kadasah, N.; Abdulghaffar, N. 2014. Motivations and barriers affecting the implementation of ISO 14001 in Saudi Arabia: an empirical investigation, Total Quality Management \& Business Excellence 25(11-12): 1352-1364. http://dx.doi.org/10.1080/14783363.2014.912038

Masternak-Janus, A. 2013. Analiza efektywności gospodarowania przedsiębiorstw przemysłowych w Polsce [Analysis of economic efficiency of industrial enterprises in Poland], Economics and Management 5(4): 58-69.

Matuszak-Flejszman, A. 2011. Factors for improving environmental management systems in Polish company according to ISO 14001, Polish Journal of Environmental Studies 20(3): 709-718 [online], [cited 15 November 2014]. Available from Internet: http://www.pjoes.com/pdf/20.3/ Pol.J.Environ.Stud.Vol.20.No.3.709-718.pdf

Mazurkiewicz, A.; Poteralska, B. 2009. Zrównoważony rozwój Polski [Sustainable development in Poland], in J. Kleer, A. Wierzbicki (Eds.). Narodowy Program Foresight "Polska 2020". Dyskusja założeń scenariuszy [National Foresight Programme "Poland 2020". Discussion of assumptions scenarios]. Warszaw: Komitet Prognoz "Polska 2000 Plus".

Medineckiene, M.; Turskis, Z.; Zavadskas, E. K. 2010. Sustainable construction taking into account the building impact on the environment, Journal of Environmental Engineering and Landscape Management 18(2): 118-127. http://dx.doi.org/10.3846/jeelm.2010.14

Nazarko, J.; Kędzior, Z. (Eds.). 2010. Uwarunkowania rozwoju nanotechnologii w województwie podlaskim. Wyniki analizy SWOT i STEEPVL [Conditions of nanotechnology development in Podlasie Province. The results of the SWOT and STEEPVL analysis]. Bialystok: BTU Press [online], [cited 25 September 2014]. Available from Internet: http://ntfp2020.pb.edu.pl/ pliki/Uwarunkowania_rozwoju_nanotechnologii_w_wojewodztwie_podlaskim_Wyniki_analiz_ STEEPVL_i_SWOT.p̄if

Nazarko, J.; Wnorowski, H.; Kononiuk, A. (Eds.). 2011. Analiza strukturalna czynników rozwoju nanotechnologii $w$ województwie podlaskim [Structural analysis of factors influencing the development of nanotechnology in the Podlaskie]. Białystok: BTU Press [online], [cited 20 September 2014]. Available from Internet: http://ntfp2020.pb.edu.pl/pliki/Analiza_strukturalna_czynnikow_ rozwoju_nanotechnologii_w_wojewodztwie_podlaskim.pdf

Neugebauer, F. 2012. EMAS and ISO 14001 in the German industry - complements or substitutes?, Journal of Cleaner Production 37: 249-256. http://dx.doi.org/10.1016/j.jclepro.2012.07.021

Newman, J.; Breeden, K. 1992. Managing in the environmental era: lessons from environmental leaders, The Columbia Journal of World Business 27(3-4): 210-221 [online], [cited 10 November 2014]. Available from Internet: http://legacy.library.ucsf.edu/tid/sva27a00/pdf;jsessionid=99897 AEC70D679A319E71FE7F4D3746E.tobacco04

Peiro-Signes, A.; Segarra-Ona, M.; Mondejar-Jimenez, J.; Vargas-Vargas, M. 2013. Analysis of the impact of ISO 14001 in the economic variables of the Spanish ceramic tile industry's companies, Boletin De La Sociedad Espanola De Ceramica y Vidrio 52(1): 15-24.

http://dx.doi.org/10.3989/cyv.22013

Popper, R. 2003. The French prospective, in M. Keenan, I. Milesand, J. Koi-Ova (Eds.). Handbook of knowledge society foresight. Dublin: European Foundation.

Radziszewska-Zielina, E. 2011. Assessment methods of partnering relations of Polish, Slovak and Ukrainian construction enterprises with the use of fuzzy logic, Archives of Civil Engineering LVII(1): 87-118. http://dx.doi.org/DOI: 10.2478/v.10169-011-0008-2 
Ratcliffe, J. 2000. Scenario building: a suitable method for strategic property planning, Property Management 18(2): 127-144 http://dx.doi.org/10.1108/02637470010328322

Rybka, I.; Bondar-Nowakowska, E. 2013. Risk of alterations to project documentation on an example of environmental engineering construction, Archives of Civil Engineering LIX(4): 499508. http://dx.doi.org/10.2478/ace-2013-0027

Salomone, R. 2008. Integrated management systems: experiences in Italian organizations, Journal of Cleaner Production 16(16): 1786-1806.

Simon, A.; Karapetrovic, S.; Casadesus, M. 2012. Evolution of integrated management systems in Spanish firms, Journal of Cleaner Production 23: 8-19.

http://dx.doi.org/10.1016/j.jclepro.2011.10.025

Srdić, A.; Šelih, J. 2011. Integrated quality and sustainability assessment in construction: a conceptual model, Technological and Economic Development of Economy 17(4): 611-626.

http://dx.doi.org/10.3846/20294913.2011.603177

Stevens, P. A.; Batty, W. J.; Longhurst, P. J.; Drew G. H. 2012. A critical review of classification of organisations in relation to the voluntary implementation of environmental management systems, Journal of Environmental Management 113: 206-212.

http://dx.doi.org/10.1016/j.jenvman.2012.08.037

Tambovceva, T.; Geipele, I. 2011. Environmental management systems experience among Latvian construction companies, Technological and Economic Development of Economy 17(4): 595-610. http://dx.doi.org/10.3846/20294913.2011.603179

Tamošaitienè, J.; Kapliński, O. 2013. Strategic Environmental Assessment (SEA) of socio-economic systems: a systematic review, Technological and Economic Development of Economy 19(4): 661-674. http://dx.doi.org/10.3846/20294913.2013.862882

Testa, F.; Rizzi, F.; Daddi, T.; Gusmerotti, N. M.; Frey, M.; Iraldo, F. 2014. EMAS and ISO 14001: the differences in effectively improving environmental performance, Journal of Cleaner Production 68: 165-173. http://dx.doi.org/10.1016/j.jclepro.2013.12.061

Wójcicki, J. M.; Ładyżyński, P. (Eds.). 2008. System monitorowania i scenariusze rozwoju technologii medycznych $w$ Polsce [The monitoring system and scenarios of medical technology development in Poland]. ROTMED Press Warszawa [online], [cited 10 September 2014]. Available from Internet: http://www.ippt.pan.pl/attachments/Foresight-ROTMED.pdf

Zhang, W.; Wang, W.; Wang, S. 2014. Environmental performance evaluation of implementing EMS (ISO 14001) in the coating industry: case study of a Shanghai coating firm, Journal of Cleaner Production 64: 205-217. http://dx.doi.org/10.1016/j.jclepro.2013.08.028

Zivkovic, S.; Takic, L.; Zivkovic, N. 2013. The improvement of environmental performances by applying ISO 14001 standard - a case study, Chemical Industry \& Chemical Engineering Quarterly 19(4): 541-552. http://dx.doi.org/10.2298/CICEQ120513088Z

Zobel, T. 2013. ISO 14001 certification in manufacturing firms: a tool for those in need or an indication of greenness?, Journal of Cleaner Production 43: 37-44.

http://dx.doi.org/10.1016/j.jclepro.2012.12.014

Zutshi, A.; Sohal, A. 2004. Environmental management system adoption by Australasian organisations: Part 1: reasons, benefits and impediments, Technovation 24 (4): 335-57.

http://dx.doi.org/10.1016/S0166-4972(02)00053-6 
Joanna EJDYS is currently an Associate Professor at the Faculty of Management, Bialystok University of Technology. She is a Vice-Dean for Research and Development and Editor of Economics and Management Journal. Research interests: quality management, foresight studies, strategic management and technology management. She published more than 30 papers on foresight studies concerning regional and national science and technology innovation policy.

Alina MATUSZAK-FLEJSZMAN is currently an Associate Professor at the Faculty of Commodity Science, Poznan University of Economics. She is a Vice-Dean of faculty and vice-president of the Polish Association of ISO 14000 and vice-president of the Polish Company of Commodity Science. Research interests: quality, environmental \& safety management, integrated management systems, strategy management, sustainable production and consumption, effectiveness and efficiency of management systems.

Michal SZYMANSKI is currently an Assistant Professor at the Faculty of Management and Economics at the Technical University of Gdansk. Research interests: integrated quality management system, environmental management system and management of private labels. Has published more than 10 papers on international management systems.

Leonas USTINOVICHIUS. Professor Dr Habil at Vilnius Gediminas Technical University and Bialystok University of Technology. Research interests: multicriteria evaluation and automated programming of technological decision in construction, operational research methods, technology of construction process, quantitative and qualitative decision-making methods, organisation and performance of construction firms.

Galina SHEVCHENKO. PhD, assistant at Vilnius Gediminas Technical University, the Faculty of Business Management, the Department of Enterprise Economics and Management. Fields of research: risk management, investment management, multi-criteria methods, sustainable development.

Agata LULEWICZ-SAS is currently an Assistant Professor at the Faculty of Management, Bialystok University of Technology. Research interests: quality, environmental \& safety management and corporate social responsibility. 